\title{
PENGGUNAAN CRUM RUBBER PADA PEMBUATAN PAVING BLOK
}

\section{Tengku Muhammad Fahri dan Johannes Tarigan}

Universitas Sumatera Utara (USU) Medan, Indonesia

Email: t.fahri@yahoo.com dan johannes.tarigan@usu.ac.id

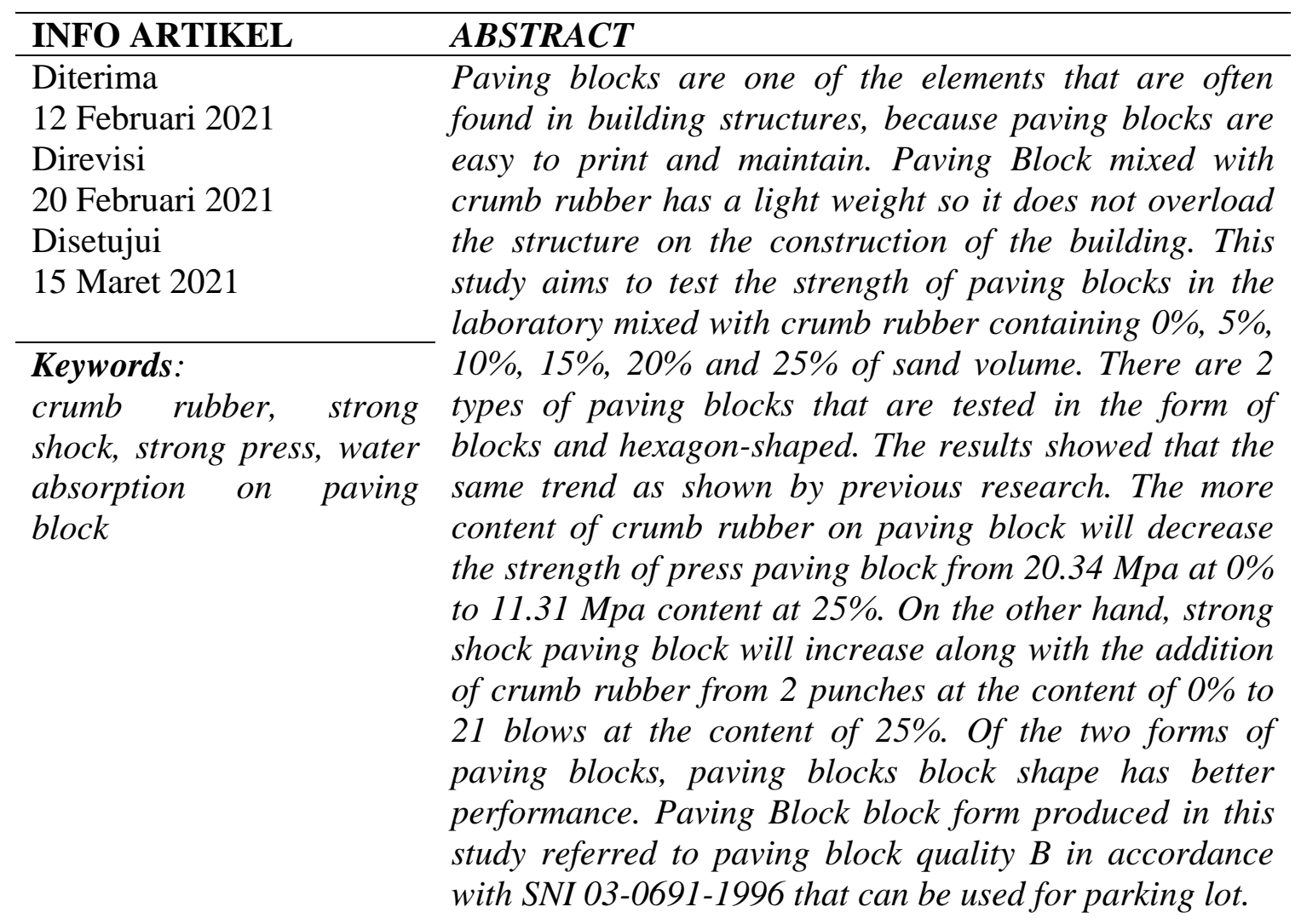

\begin{abstract}
ABSTRAK
Paving block merupakan salah satu elemen yang sering ditemukan dalam struktur bangunan, karena paving block mudah untuk dicetak dan dirawat. Paving Block yang dicampur dengan crumb rubber mempunyai berat yang ringan sehingga tidak terlalu membebani struktur pada konstruksi bangunan. Penelitian ini bertujuan untuk menguji kekuatan paving block di laboratorium yang dicampur crumb rubber dengan kandungan 0\%, 5\%, $10 \%, 15 \%, 20 \%$ dan $25 \%$ dari volume pasir. Ada 2 jenis paving block yang diuji yaitu berbentuk balok dan berbentuk heksagon. Hasil penelitian menunjukan bahwa tren yang sama seperti yang ditunjukan oleh penelitian sebelumnya. Semakin banyak kandungan crumb rubber pada paving block akan menurunkan kuat tekan paving block dari 20,34 Mpa pada kandungan 0\% hingga 11,31
\end{abstract}


Kata Kunci: crumb rubber, kuat kejut, kuat tekan, absorpsi air pada paving block
Mpa pada kandungan 25\%. Di lain pihak, kuat kejut paving block akan meningkat seiring dengan penambahan crumb rubber dari 2 pukulan pada kandungan $0 \%$ hingga 21 Pukulan pada kandungan 25\%. Dari kedua bentuk paving block, paving block bentuk balok memiliki performasi yang lebih baik. Paving Block bentuk balok yang dihasilkan dalam studi ini termaksud paving block mutu B sesuai dengan SNI 03-0691-1996 yang dapat digunakan untuk pelataran parkir.

Coresponden Author

Email: t.fahri@yahoo.com

Artikel dengan akses terbuka dibawah lisensi

\section{Pendahuluan}

Limbah ban merupakan salah satu penyumbang sampah terbesar dan setiap tahun meningkat secara drastis yang di karenakan adanya mobil-mobil yang sangat murah dan daya beli masyarakat yang tinggi (Kurniadi \& Suhada, 2014). Skema mobil murah ramah lingkungan juga semakin memperparah jumlah limbah ban tersebut, menurut data BPS (Badan Pusat Statistik) pertumbuhan kendaraan di indonesia meningkat dari tahun ke tahun, pada tahun 2017 jumlah kenderaan di indonesia telah mencapai 138.556.669 unit dan akan terus meningkat seiring penambahan jumlah kenderaan di dalam negeri (Muawal, 2020).

Limbah dari ban kendaraan tersebut merupakan material yang tidak dapat digunakan oleh organisme jadi sifatnya permanen dan jika dibakar akan terjadi pembakaran yang tidak sempurna yang menghasilkan karbon monoksida (CO) dan karbon dioksida $\left(\mathrm{CO}_{2}\right)$ yang sangat berbahaya bagi kesehatan dan lingkungan karena limbah ban tersebut sulit diuraikan oleh lingkungan dan sangat tahan terhadap serangan kimia dan asam (Sembel, 2015). Oleh karena itu, telah diperoleh terobosan baru untuk pemanfaatan limbah ban bekas tersebut untuk rigit paving block yaitu untuk memberikan sifat lentur dan di harapkan dapat memberi sifat kejut, absorpsi air dan kuat tekan sesuai dengan mutu yang tercapai (SNI 03-0691-1996) tentang paving block baik secara fisis dan mekanis (Sebayang et al., 2012).

Paving block ini memiliki keuntungan karena perencanaan yang sederhana tidak banyak memerlukan perawatan, cocok untuk lalu lintas dan kontruksi yang standar dan cocok pula untuk tanah dasar yang memiliki nilai CBR (California Bearing Ratio) yang rendah (Penteado et al., 2016). Disamping beratnya yang relatif lebih ringan dari cor beton biasa sehingga menjadikan satu penompang utama agar pondasi sekitarnya tetap stabil tetapi kelemahan paving block adalah tingkat kenyamanan jalan/lalu lintas karena nilai kelenturannya (Adibroto, 2014).

Klasifikasi paving blok:

1. Mutu paving block type A digunakan untuk jalan, (Kuat Tekan $35 \mathrm{Mpa}$ s/d 40 Mpa). 
2. Mutu paving block type B digunakan untuk pelataran parkir, (Kuat Tekan 17 Mpa s/d $20 \mathrm{Mpa})$.

3. Mutu paving block type $\mathrm{C}$ digunakan untuk pejalan kaki, (Kuat Tekan 12.5 mpa s.d $15 \mathrm{Mpa})$.

4. Mutu paving block type D digunakan untuk taman dan pengguna lainnya, (Kuat Tekan 8.5 Mpa s/d $10 \mathrm{Mpa}$ ).

Penelitian terkait inovasi campuran material untuk pembuatan paving block sudah banyak dilakukan. Seperti yang dilakukan oleh (Sembiring, 2017), mereka melakukan uji tekan dan serapan air pada paving block dengan bahan pasir kasar, batu kacang, dan pasir halus. Hasil penelitian ini adalah kuat tekan paving block yang dihasilkan adalah $11,7 \mathrm{MPa}$ dan daya serap air 16\%. (Triyono, 2010) meneliti pemanfaatan limbah tempurung kelapa sawit untuk pembuatan paving block. Hasil dari penelitian ini adalah komposisi campuran material yang digunakan untuk mendapatkan kuat tekan paving block standart, selain itu penggunaan material lain untuk pembuatan paving block adalah crumb rubber (Prasetyo, 2017). Berdasarkan dari hasil pengujian beberapa literature yang berkaitan dengan penggantian agregat dengan crumb rubber untuk paving block telah disimpulkan bahwa semakin banyak penambahan crumb rubber pada campuran paving block akan mengurangi kuat tekan paving block tersebut sampai tingkat tertentu, akan tetapi untuk pengujian kuat kejut menunjukkan juga bahwa paving block yang di isi crumb rubber memiliki peningkatan yang sangat signifikan dalam hal uji ketangguhan, penyerapan energi, dapat menahan beban menyerapan dinamis dan menahan penyebaran retak (Tsani \& Mudiyono, 2019). Atas dasar uraian tersebut maka dilakukan penelitian ini untuk mendapatkan nilai kuat kekan paving block dengan bahan crumb rubber dengan beberapa komposisi campuran material (diwana et al., 2020).

\section{Metode Penelitian}

Penelitian ini dilakukan dengan melakukan pembuatan benda uji paving block yang selanjutnya akan di uji di laboratorium. Sample paving blok yang dibuat adalah berbentuk heksagon dengan variansi campuran crumb rubber sebesar 0\%, 5\%, 10\%, $15 \%, 20 \%$ dan $25 \%$ dari total volume agregat halus dengan campuran $1: 4$ seperti Tabel 1.

\section{Tabel 1}

Sampel Paving Block Berbentuk Heksagon

\begin{tabular}{cccc}
\hline No & $\begin{array}{c}\text { Paving Block } \\
\text { heksagon }\end{array}$ & $\begin{array}{c}\text { Waktu } \\
\text { Perawatan }\end{array}$ & $\begin{array}{c}\text { Jumlah } \\
\text { (buah) }\end{array}$ \\
\hline 1 & $0 \%$ crumb rubber & 28 hari & 3 \\
2 & $5 \%$ crumb rubber & 28 hari & 3 \\
3 & $10 \%$ crumb rubber & 28 hari & 3 \\
4 & $15 \%$ crumb rubber & 28 hari & 3 \\
5 & $20 \%$ crumb rubber & 28 hari & 3 \\
6 & $25 \%$ crumb rubber & 28 hari & 3 \\
\hline
\end{tabular}

Sumber: Hasil perhitungan 
Benda uji keseluruhan yang akan dibuat sebanyak 18 buah, benda uji paving block berbentuk heksagon.

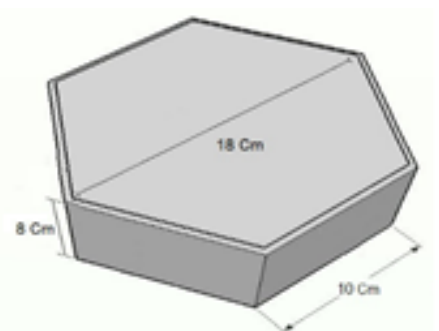

Gambar 1

Paving Block Berbentuk Heksagon

Penelitian ini akan di buat beberapa sample paving block balok persegi empat dengan variansi campuran crumb rubber sebesar 0\%, 5\%, 10\%, 15\%,20\% dan 25\% dari total volume agregat halus dengan campuran 1:4 seperti Tabel 2.

Tabel 2

Sampel Paving Block Berbentuk Balok Persegi Empat

\begin{tabular}{cccc}
\hline No & Paving Block balok & $\begin{array}{c}\text { Waktu } \\
\text { Perawatan }\end{array}$ & $\begin{array}{c}\text { Jumlah } \\
\text { (buah) }\end{array}$ \\
\hline 1 & $0 \%$ crumb rubber & 28 hari & 3 \\
\hline 2 & $5 \%$ crumb rubber & 28 hari & 3 \\
\hline 3 & $10 \%$ crumb rubber & 28 hari & 3 \\
\hline 4 & $15 \%$ crumb rubber & 28 hari & 3 \\
\hline 5 & $20 \%$ crumb rubber & 28 hari & 3 \\
\hline 6 & $25 \%$ crumb rubber & 28 hari & 3 \\
\hline \multicolumn{4}{c}{ Sumber: Hasil perhitungan }
\end{tabular}

Benda uji yang akan dibuat adalah sebanyak 18 buah. Benda uji paving block berbentuk balok persegi enam

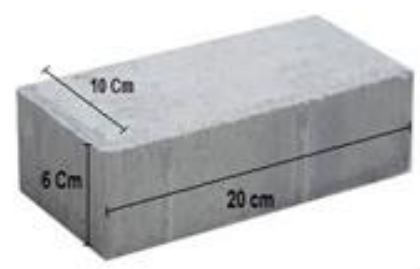

Gambar 2

Paving Block Balok Persegi Empat

\section{Hasil dan Pembahasan}

1. Kuat Tekan

Pada peraturan beton ASTM C37/C39 M-4 kekuatan material beton dinyatakan oleh kuat tekan benda uji paving blok dengan satuan mpa, berubah dari $\mathrm{kg} / \mathrm{cm}^{2}$ menjadi mutu beton (K) dan (Mpa), disebabkan karena SNI mengacu pada peraturan ACI 318, Pengujian Kuat Tekan Dilakukan Pada Umur Beton Hari Ke 28 Dengan Menggunakan Jacking Hydraulik (Jonbi \& Fulazzaky, 2020). 
Prosedur pengujian kuat tekan beton yaitu:

a. Keluarkan benda uji dari tempat perawatan, jemur selama 24 jam apabila dari perawatan dengan perendaman

b. Timbang berat benda uji sebelum dilakukan pengujian

c. Masukkan benda uji ke mesin kompres dan hidupkan mesin sampai jarum pada dial pembacaannya tidak bertambah lagi / benda uji sudah runtuh

d. Catat kuat tekan benda uji tersebut

Perhitungan kuat tekan pada beton menggunakan persamaan sebagai berikut.

$$
\begin{aligned}
& f^{\prime} c=\text { P/A } \\
& \text { Dengan : } \\
& f^{\prime} c=\text { Kuat Tekan Beton }(\mathrm{Kg} / \mathrm{cm} 2) \\
& P=\text { Beban Tekan / Hancur }(K g) \\
& A=\text { Luas Penampang Tertekan Rata }- \text { Rata }\left(\mathrm{cm}^{2}\right)
\end{aligned}
$$

Hasil pengujian kuat tekan paving blok pada penelitian ini disajikan pada Tabel 3 dan Tabel 4.

Tabel 3

Hasil Test Kuat Tekan Pada Paving Block Berbentuk Balok

\begin{tabular}{clcc}
\hline No & Variasi Benda uji & $\begin{array}{c}\text { Berat } \\
\text { Paving }\end{array}$ & $\begin{array}{c}\text { Kuat Tekan } \\
\text { (Mpa) }\end{array}$ \\
\hline 1 & $0 \%$ Crumb Rubber & $1,899 \mathrm{~kg}$ & 20.34 \\
2 & $5 \%$ Crumb Rubber & $1,722 \mathrm{~kg}$ & 18.40 \\
3 & $10 \%$ Crumb Rubber & $1,689 \mathrm{~kg}$ & 16.33 \\
4 & $15 \%$ Crumb Rubber & $1,634 \mathrm{~kg}$ & 15.83 \\
5 & $20 \%$ Crumb Rubber & $1,593 \mathrm{~kg}$ & 12.81 \\
6 & $25 \%$ Crumb Rubber & $1,260 \mathrm{~kg}$ & 11.31 \\
\hline
\end{tabular}

Sumber: Hasil Perhitungan

Tabel 4

Hasil Test Kuat Tekan Pada Paving Block Berbentuk Heksagon

\begin{tabular}{lccc}
\hline No & Variasi Benda Uji & $\begin{array}{c}\text { Berat } \\
\text { Paving }\end{array}$ & $\begin{array}{c}\text { Kuat } \\
\text { Tekan } \\
\text { ( Mpa) }\end{array}$ \\
\hline 1. & $0 \%$ Crumb Rubber & $2,380 \mathrm{~kg}$ & 17.07 \\
2. & $5 \%$ Crumb Rubber & $2,370 \mathrm{~kg}$ & 15.26 \\
3. & $10 \%$ Crumb Rubber & $2,366 \mathrm{~kg}$ & 14.87 \\
4. & $15 \%$ Crumb Rubber & $2,299 \mathrm{~kg}$ & 11.05 \\
5. & $20 \%$ Crumb Rubber & $2,201 \mathrm{~kg}$ & 11.05 \\
6. & $25 \%$ Crumb Rubber & $2,179 \mathrm{~kg}$ & 5.58 \\
\hline
\end{tabular}

Sumber: Hasil perhitungan

2. Kuat kejut

Beban dapat dikelompokan sebagai beban statik dan beban dinamik, dimana salah satu bentuk dari beban dinamik adalah beban kejut yang mana beberapa beban diterapkan dan dihilangkan secara tib-tiba (Udawattha et al., 2017). Beban kejut dihasilkan apabila dua benda bertumbukan atau apabila benda jatuh dan mengenai suatu struktur, uji beban kejut ini menggunakan alat impact testing 
machine (Dahlan et al., 2013). Meningkatkan ketahanan kejut atau kemampuan menyerap energy dari beban dinamis merupakan salah satu test untuk mengukur perkuatan paving blok (Al-Furqon, 2021), yang paling sederhana pada uji kejut adalah drop weight test atau uji jatuh beban secara bebas dan berulang, ACI 544 dan ASTM-D 1557 sudah merekomendasikan bahwa uji kejut ini dengan menjatuhkan palu (hammer) seberat 4,5 kg secara bebas dari ketinggian 18 inch $(46 \mathrm{~cm})$ yang diletakkan pada benda uji. Palu dijatuhkan berulang kali dan diamati kondisi retak pertama kali sampai failure, uji kejut ini menghasilkan jumlah pukulan yang diperlukan untuk menyebabkan benda uji failure (Fauzy et al., 2018). Jumlah ini berfungsi sebagai perkiraan kualitatif dari energy yang diserap oleh benda uji hingga hancur (failure). Adapun hasil kuat kejut dari benda uji pada penelitian ini disajikan pada Tabel 5 dan Tabel 6.

\section{Tabel 5}

\begin{tabular}{|c|c|c|c|}
\hline \multicolumn{4}{|c|}{ Hasil Test Kuat Kejut Pada Paving Block Berbentuk Balol } \\
\hline No & Variasi Benda uji & Retak Halus & Retak Hancur \\
\hline 1 & 0\% Crumb Rubber & 0 & 2 pukulan \\
\hline 2 & 5\% Crumb Rubber & 0 & 2 pukulan \\
\hline 3 & $10 \%$ Crumb Rubber & 2 pukulan & 6 pukulan \\
\hline 4 & $15 \%$ Crumb Rubber & 7 pukulan & 14 pukulan \\
\hline 5 & $20 \%$ Crumb Rubber & 10 pukulan & 21 pukulan \\
\hline 6 & $20 \%$ Crumb Rubber & 11 pukulan & 35 pukulan \\
\hline
\end{tabular}

Sumber: Hasil perhitungan

Tabel 6

\begin{tabular}{cccc}
\multicolumn{5}{c}{ Hasil Test Kuat Kejut Pada } & Paving Block Berbentuk Heksagon \\
\hline No & Variasi Benda uji & Retak Halus & Retak Hancur \\
\hline 1 & $0 \%$ Crumb Rubber & 19 pukulan & 20 pukulan \\
2 & $5 \%$ Crumb Rubber & 46 pukulan & 52 pukulan \\
3 & $10 \%$ Crumb Rubber & 80 pukulan & 95 pukulan \\
4 & $15 \%$ Crumb Rubber & 90 pukulan & 98 pukulan \\
5 & $20 \%$ Crumb Rubber & 92 pukulan & 105 pukulan \\
6 & $25 \%$ Crumb Rubber & 110 pukulan & 120 pukulan \\
\hline \multicolumn{5}{c}{ Sumber: Hasil perhitungan }
\end{tabular}

3. Daya absorpsi

Pada penelitian ini, tahap perendaman yang dilakukan untuk mengitung nilai daya serap air ASTM C-20-00-2005, yaitu sebagai berikut:

a. Setelah umur beton mencapai 28 hari setelah reaksi hidrasi pada semen selesai sampel beton di keringkan dengan cara oven sampai mencapai berat konstan

b. Setelah di keluarkan dari oven, sampel paving di timbang

c. Merendam sampel beton selama dan 28 hari.

d. Kemudian di buat sampel beton dalam kondisi SSD, setelah itu menimbang masing-masing sampel beton selama batas waktu perendaman tersebut di atas dan membandingkan perbedaan antara berat sampel dalam kondisi SSD dengan berat sampel dalam kondisi kering oven. 
Penyerapan air dihitung sebagai berikut:

$$
\text { Penyerapan air }=\frac{\mathrm{A}-\mathrm{B}}{\mathrm{B}} \times 100 \%
$$

Keterangan:

$$
\begin{aligned}
& \mathrm{A}=\text { Berat paving block basah } \\
& \mathrm{B}=\text { Berat paving block kering } \\
& \text { Adapun hasil pengujian absorpsi dari penelitian ini disajikan pada Tabel } 7 \\
& \text { dan Tabel } 8 .
\end{aligned}
$$

Tabel 7

Hasil Absorpsi Air Pada Paving Block Berbentuk Balok

\begin{tabular}{llc}
\hline No & $\begin{array}{c}\text { Variasi Campuran } \\
\text { Crumb Rubber }\end{array}$ & Serapan Air ( \% ) \\
\hline 1 & $0 \%$ Crumb Rubber & 6.85 \\
2 & $5 \%$ Crumb Rubber & 4.48 \\
3 & $10 \%$ Crumg Rubber & 5.16 \\
4 & $15 \%$ Crumb Rubber & 4.90 \\
5 & $20 \%$ Crumb Rubber & 5.28 \\
6 & $25 \%$ Crumb Rubber & 4.91 \\
\hline
\end{tabular}

Sumber: Hasil perhitungan

Tabel 8

\begin{tabular}{llc}
\multicolumn{3}{c}{ Hasil Absorpsi Air Pada Paving Block Berbentuk Heksagon } \\
\hline No & Variasi Campuran Crumb Rubber & Serapan Air ( \% ) \\
\hline 1 & $0 \%$ Crumb Rubber & 12.05 \\
2 & $5 \%$ Crumb Rubber & 8.65 \\
3 & $10 \%$ Crumg Rubber & 5.63 \\
4 & $15 \%$ Crumb Rubber & 7.14 \\
5 & $20 \%$ Crumb Rubber & 7.91 \\
6 & $25 \%$ Crumb Rubber & 7.44 \\
\hline
\end{tabular}

Sumber: Hasil perhitungan

Setelah dilakukan beberapa pengujian dari paving block dengan variasi campuran crumb rubber yang berbeda dan hasil perbandingan dari pengujian dapat dilihat bahwa untuk kuat kejut, kuat tekan dan absorpsi air pada paving block berbentuk balok dan paving block berbentuk heksagon memiliki perbedaan pada masing-masing sampel.

Pada tabel hasil test kuat kejut di atas menunjukan jumlah pukulan yang mengakibatkan kerusakan pada paving block, pada campuran $25 \%$ crumb rubber pada paving block berbentuk heksagon lebih tinggi menahan kuat kejut dari pada campuran $25 \%$ crumb rubber pada paving block berbentuk balok hal ini menunjukan bahwa paving block balok lebih rendah menahan kuat kejut dari pada paving block berbentuk heksagon.

Pada tabel hasil kuat tekan di atas menunjukan jumlah kuat tekan yang mengakibatkan kehancuran pada paving block berbentuk balok dan paving block berbentuk heksagon, kuat tekan pada paving block berbentuk balok memiliki kuat tekan di atas dari paving block berbentuk heksagon dengan nilai 18.40 Mpa untuk campuran 
5\% crumb rubber untuk paving block berbentuk balok. Pada tabel hasil absorpsi air juga menunjukan jumlah serapan air dari setiap sampel paving block berbentuk balok dan paving block berbentuk heksagon, untuk setiap bentuk dan variasi campuran crumb rubber memiliki nilai serapan air yang berbeda, paving block berbentuk balok lebih sedikit menyerap air di bandingkan paving block berbentuk heksagon.

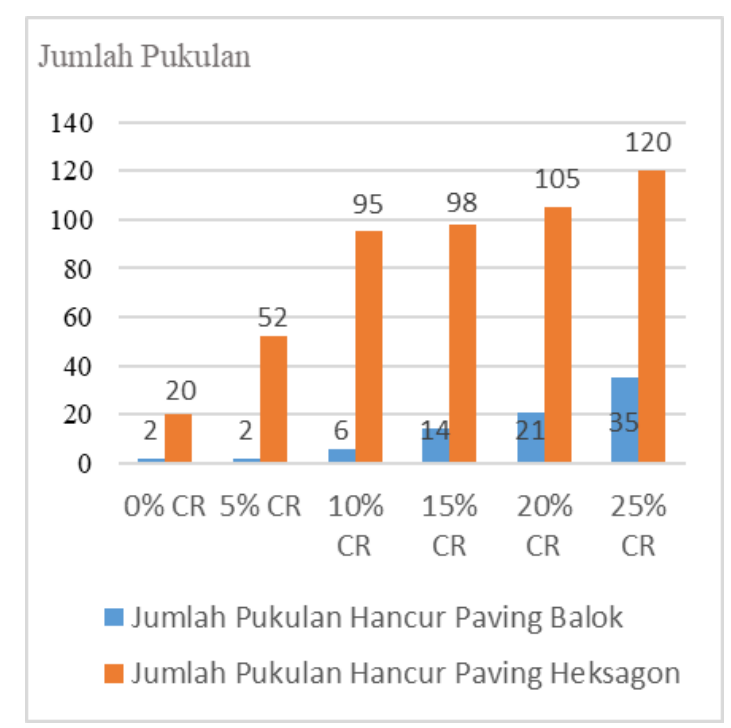

\section{Gambar 3}

Perbandingan Hasil Test Kuat Kejut Pada Paving Block Berbentuk Balok dan Paving Block Berbentuk Heksagon

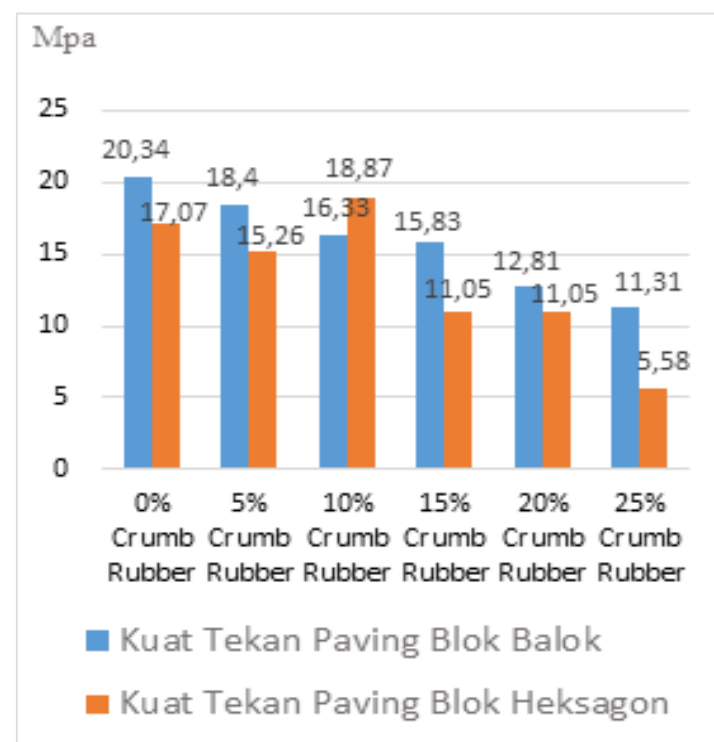

Gambar 4

Perbandingan Hasil Test Kuat Tekan Pada Paving Block Berbentuk Balok dan Paving Block Berbentuk Heksagon 


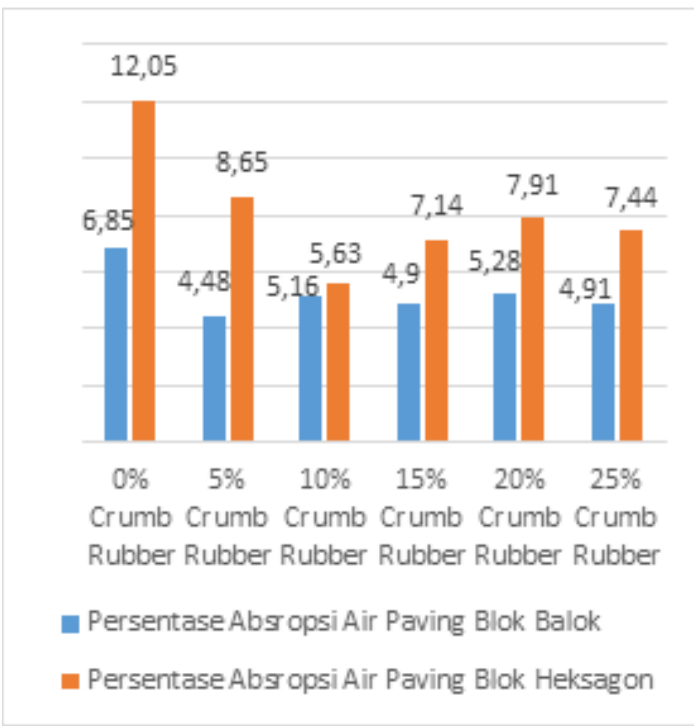

Gambar 5

Perbandingan Hasil Test Persentase Absorpsi Air Pada Paving Block Berbentuk Balok dan Paving Block Berbentuk Heksagon

\section{Kesimpulan}

Berdasarkan dari hasil analisis dan hasil uji terhadap beberapa benda uji maka dengan ini dapat di simpulkan bahwa kuat kejut pada material yang mengandung campuran crumb rubber lebih tinggi dari pada tanpa campuran crumb rubber, ini menunjukan bahwa material dengan campuran crum rubber memiliki daya penyerapan beban dinamis dan dapat menahan perambatan terak. Kuat tekan dengan material campuran crumb rubber untuk semua variasi percobaan menunjukkan bahwa semakin besar kadar campuran crumb rubber akan mengakibatkan kuat tekan paving block semakin lemah. Peningkatan campuran crumb rubber pada semua variasi percobaan menunjukan semakin besar kandungan material crumb rubber akan mengurangi kepadatan kering penyerapan air pada campuran crumb rubber akan menurun. Berat unit paving block dengan campuran crumb rubber untuk semua tingkat variasi berkurang seiring di tambahkannya material crumb rubber pada paving block. 


\section{BIBLIOGRAFI}

Adibroto, F. (2014). Pengaruh Penambahan Berbagai Jenis Serat Pada Kuat Tekan Paving Block. Jurnal Rekayasa Sipil (Jrs-Unand), 10(1), 1-11.

Al-Furqon, Y. H. (2021). Pemanfaatan Serbuk Genteng Sebagai Bahan Tambah Paving Block Menggunakan Dengan Metode Penekanan Plat Desak Pyramid Pemanfaatan Serbuk Genteng Sebagai Bahan Tambah Paving Block Menggunakan Dengan Metode Penekanan Plat Desak Pyramid. Universitas Muhammadiyah Surakarta.

Dahlan, M., Slamet, S., \& Gunawan, B. (2013). Prototipe Mesin Press Otomatis Dengan Sistem Pneumatik Berbasis Programmable Logic Controller (P Lc) Untuk Produksi Paving Blok Berstandar Nasional Indonesia (Sni). Prosiding Snst Fakultas Teknik, 1(1).

Diwana, M. R., Bahri, S., \& Sulaiman, Y. H. (2020). Optimalisasi Komposisi Agregat Beton Paving Block Mutu Tinggi. Jurnal Sipil Sains Terapan, 2(02).

Fauzy, A. R., Limantara, A. D., \& Purnomo, Y. C. S. (2018). Pemanfaatan Limbah Hasil Pembuatan Anyaman Berbahan Bambu Sebagai Campuran Standard Mixdesign Paving Block. Jurnal Manajemen Teknologi \& Teknik Sipil, 1(1), 137147.

Jonbi, J., \& Fulazzaky, M. A. (2020). Modeling The Water Absorption And Compressive Strength Of Geopolymer Paving Block: An Empirical Approach. Measurement, 158, 107695.

Kurniadi, S., \& Suhada, A. K. (2014). Pemanfaatan Limbah Ban Dalam Bekas (Inner Tube Project). Product Design, 3(1), 180219.

Muawal, N. F. (2020). Pengaruh Kualitas Pelayanan Terhadap Loyalitas Konsumen Dengan Kepuasan Konsumen Sebagai Variabel Mediasi: Studi Kasus Pada Pelanggan Bengkel Cipicung Motor Baleendah Bandung. Uin Sunan Gunung Djati Bandung.

Penteado, C. S. G., De Carvalho, E. V., \& Lintz, R. C. C. (2016). Reusing Ceramic Tile Polishing Waste In Paving Block Manufacturing. Journal Of Cleaner Production, $112,514-520$.

Prasetyo, G. A. D. (2017). The Performance Of Hot Rolled Sheet Wearing Course Stabilized Using Crumb Rubber. Universitas Muhammadiyah Surakarta.

Sebayang, S., Diana, I. W., \& Purba, A. (2012). Perbandingan Mutu Paving Block Produksi Manual Dengan Produksi Masinal. Rekayasa: Jurnal Ilmiah Fakultas Teknik Universitas Lampung, 15(2), 139-150.

Sembel, D. T. (2015). Toksikologi Lingkungan. Penerbit Andi. 
Sembiring, A. (2017). Uji Kuat Tekan Dan Serapan Air Pada Paving Block Dengan Bahan Pasir Kasar, Batu Kacang, Dan Pasir Halus. Juriti (Jurnal Teknik Industri Prima), 1(1).

Triyono, D. D. (2010). (Abstrak) Pemanfaatan Limbah Tempurung Kelapa Sawit Untuk Pembuatan Paving Block. Universitas Negeri Semarang.

Tsani, N. S., \& Mudiyono, R. (2019). Analisis Bahu Jalan Menggunakan Perkerasan Paving Block. Reviews In Civil Engineering, 3(2).

Udawattha, C., Galabada, H., \& Halwatura, R. (2017). Mud Concrete Paving Block For Pedestrian Pavements. Case Studies In Construction Materials, 7, 249-262. 